INTERNATIONAL BULLETIN OF BACTERIOLOGICAL NOMENCLATURE AND TAXONOMY

Volume 4 April 15, 1954 No. 2 pp 109-114

\title{
REPORT OF THE SUBCOMMITTEE ON VIRUSES (1953)
}

The Virus Subcommittee of the International Nomenclature Committee met in Rome on the 8th and 9th September, 1953. There were present:-
Dr. C.H. Andrewes (Chairman)
Dr. F.C. Bawden
Dr. C.W. Bennett
Dr. G.H. Bergold
Dr. S. Gard
Prof. G. Henneberg
Dr. E. Kohler
Prof. F. Magrassi
Dr. I. W. Prentice
Dr. G. Rake
Prof. T.H. Thung
Prof. E. van Slogteren
Dr. H. Koprowski (alternate for Sir Macfarlane Burnet)
Dr. J.R. Paul (alternate for Dr. W. McD. Hammon)
Dr. A.B. Sabin (alternate for Dr. P. Lepine)

The Subcommitte unanimously reported to the maincommittee as follows.

After studying reports of the study groups appointed in 1950 and 1952 they decided to reiterate the conclusions of the meeting in 1950 that at present "the use of systems of classification for and the application of binomials to viruses as a whole are undesirable and should be discouraged". They also recommended that the starting date for valid Linnean nomenclature for viruses should not yet be determined and that until this was done names for viruses already proposed should have no standing in bacteriological nomenclature.

They proposed that names suggested by study groups of the subcommittee be accepted after further study as names for provisional international usage. These names were not proposed as binomial names of Linnean type as no grouping beyond the equivalent of the generic level is possible at the moment. They further recommended that no other names than those proposed by the study groups and accepted by the committee should have any official status.

The study groups for the bacteriophages and for arthropodborne encephalitides did not consider that viruses in their groups were ripe for application of binomials. 
The Chlamydozoaceae group recommended that this group be considered as belonging to the Rickettseales; the report was accepted and the group will thus be now considered together with bacteria and will be outside the purview of the virus subcommittee.

The other reports were accepted with some modifications and the following names of groups and members were proposed (groups and members are equivaldnt to genera and species in the Linnean system):

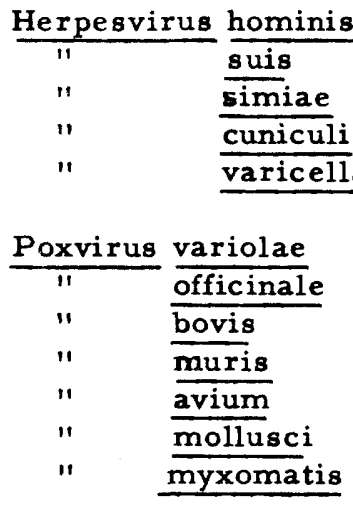

$\frac{\text { Poliovirus hominis }}{\text { " }}$

$\frac{\text { Myxovirus influenzae }-A}{" 1}-B$

" " $-\mathrm{C}$

$\begin{array}{lll}" & \begin{array}{l}\text { pestis-galli } \\ "\end{array} & \begin{array}{l}\text { (fowl plague) } \\ \text { (Newcastle disease) }\end{array} \\ \text { (multiforme } & \text { parotitidis } & \text { (mump) }\end{array}$ (herpes simplex virus)

(pseudorabies)

(B virus)

(Virus III)

(varicella)

(smallpox)

(vaccinia)

(cow-pox)

(ectromelia, mouse-pox)

(fowl-pox)

(molluscum contagiosum)

(rabbit myxoma)

(human poliomyelitis)

(mouse encephalomyelitis, TO type)

Insect-pathogenic viruses

Polyhedrovirus bombycis

and 6 other group members (efficiens, reprimens, olethrium, campeoles, percemptor, fumiferanae)

Capsulavirus calyptum

and 5 other group members (daboium, latheticum, thompsonium, clistorhabdion, brassicae and nosodes).

Globovirus rotundum

Moratorvirus nudum. 
The group members are as described by Bergold and by Steinhaus (Ann. N. Y. Acad. Sci. 56:495, 517. 1953).

These non-Linnean names shall not have ascription to particular authors, nor shall the equivalent of type species be designated. However, type strains shall be deposited with appropriate culture collections. All these names with the suffix "-virus" will be of the neuter gender. Italics should be used for the names in scientific papers. Capital letters should be used for groups.

It is suggested that the list of group members should be published in the International Bulletin of Nomenclature and should be added to or revised from time to time; also that the included groups and group members should be described in scientific journals - the descriptions being furnished by study groups and approved by the virus subcommittee. It is not proposed to create any new study groups immediately but to await the results of the present proposals.

\section{H. Andrewes, Chairman}

\section{MEMBERS OF THE VIRUS SUBCOMMIT TEE OF THE INTERNATIONAL NOMENCLATURE COMMITTEE}

\section{Animal Viruses}

Dr. C.H. Andrewes (Chairman) Dr. Sven Gard, National Institute for Med. Res. Dept. of Virus Research, The Ridgeway, Karolinska Institutet, Mill Hill, London, N. W. 7, Eng. Box 764

Stockholm 1, Sweden

Dr. G.H. Bergold,

Laboratory of Insect Path.

Dr. W. McD. Hammon, P.O. Box 490 ,

Sault Ste. Marie, Ontario, Canada

Dept. of Epidemiology, Grad. Sch. of Pub. Health, University of Pittsburgh, Pittsburgh 13, Pa., USA.

Sir Macfarlane Burnet, F.R.S., Walter and Eliza Hall Institute, Prof. G. Henneberg, Royal Melbourne Hospital, Parkville N2, Melbourne, Robert Koch Inst. far Hyg. Fohrerstrasse 2, Australia. Berlin N65, Germany 
Dr. P. Lepine,

Institut Pasteur,

25 Rue du Docteur Roux,

Paris $\mathrm{XV}^{\mathrm{e}}$, France

Prof. F. Magrassi,

Instituto di Patologia Medica,

Universita di Napoli,

Piazza L. Miraglia,

Napoli, Italy.
Dr. J. $\phi$ rskov,

Statens Seruminstitut, Amager Boulevard 80, Copenhagen, Denmark.

Dr. G. Rake,

E.R. Squibb and Sons,

Squibb Building, 745 Fifth Avenue

New York 22, N.Y. USA.

\section{$\underline{\text { Plant Viruses }}$}

Dr. L.M. Black,

Department of Botany,

University of Illinois

Urbana, Ill., USA.

Dr. A. Bitancourt, Instituto Biologico,

Caixa Postal 119-A,

Sao Paulo, Brazil

Dr. P. Limasset,

Station Centrale de Path. Veg.

Route-de-St. Cyr,

Versailles, France

Dr. C.W. Bennett,

Sugar Plant Investigations,

U.S. Dept. of Agric.

P.O. Box 31 ,

Riverside, Calif., USA.

Dr. I.W. Prentice,

Plant Pathology Lab.

Ministry of $\mathrm{Agr}$. and Fish.

Milton Road,

Harpenden, Herts.,

England
Dr. F.C. Bawden, F.R.S.,

Dept. of Plant Pathology,

Rothamsted Exp. Sta.

Harpenden, Herts.

England

Dr. E. Kohler,

Institut far Virusforschung,

Dornbergstrasse $25 / 27$,

Celle, Germany

Prof. T.H. Thung

Institut voor Plantenziektenkundig Onderzoek,

Binnenhaven $4 a$,

Wageningen, Holland

Dr. F.P. McWhorter,

Botany and Plant Pathology

Department,

Oregon State College,

Corvallis, Ore., USA.

Prof. E. van Slogteren,

Laboratorium voor

Bloembollen-Underzoek,

Lisse, Holland 
BACTERIOLOGICAL NOMENCLATURE

AND TAXONOMY

\title{
Bacterial Viruses
}

Dr. J. Craigie, O.B.E., F.R.S.,

Imperial Cancer Research Fund Laboratories,

Burtonhole Lane,

Mill Hill, London, N.W. 7., England

\section{MEMBERS OF THE SUBSECTIONS OF THE VIRUS SUBCOMMITTEE}

\section{Arthropod-borne Encephalitis Viruses}

$\begin{array}{cc}\text { Dr. P. Lepine } & \text { Dr. P.K. Olitsky, } \\ \text { (see Animal Viruses) } & \begin{array}{r}\text { Rockefeller Institute for } \\ \text { Medical Research, }\end{array} \\ \text { Dr. W. McD. Hammon } & \text { 66th St. and York Ave., } \\ \text { (see Animal Viruses) } & \text { New York 21, N.Y. USA. }\end{array}$

\section{Influenza Group}

Dr. C.H. Andrewes and

Sir Macfarlane Burnet

(see Animal Viruses)
Dr. F.B. Bang,

The Johns Hopkins Hosp.,

Baltimore 5, Md., USA.

\section{Insect-pathogenic Viruses}

\author{
Dr. G.H. Bergold \\ (see Animal Viruses) \\ Dr. G.R. Wyatt, \\ Laboratory of Insect Path. \\ P.O. Box 490 \\ Dr. E. A. Steinhaus, \\ Sault Ste. Marie, \\ Laboratory of Insect Path. Ontario, Canada \\ Div. of Biol. Control, \\ College of Agriculture, \\ Dr. K. M. Hughes and \\ Berkeley, Calif., USA. \\ Dr. F.T. Bird, \\ c/o Dr. G.H. Bergold. \\ Phage Group \\ Dr. J. Craigie (see Bacterial Viruses) \\ Dr. M.H. Adams, \\ Dept. of Microbiology, \\ University of New Y ork, \\ New York, N.Y. USA. \\ Dr. P. Nicolle, \\ Institut Pasteur, \\ 25 Rue du Docteur Roux, \\ Paris, XV $V^{e}$, France
}




\section{Pox Group}

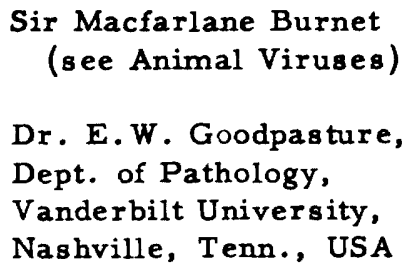

Dr. E.S. Horgan

Virus Research Institute, P.O. Box 49, Entebbe, Uganda, East Africa

\section{Poliomyelitis Group}

Dr. J.H.S. Gear,

South African Institute for Medical Research, Hospital Street,

Johannesburg, South Africa

Dr. H. von Magnus, Statens Seruminstitut, Amager Blvd. 80, Copenhagen, Denmark
Prof. R. Gornnert,

Chemotherapeutisches Laboratorium der Farbenfabriken Bayer, Wuppertal-Elberfeld, Germany
Dr. J.R. Paul, Section of Preventive Med. Yale University School of Medicine, 333 Cedar Street, New Haven 11, Conn., U.S.A.

\section{Herpes Group}

Dr. C.H. Andrewes (see Animal Viruses)

Dr. A.B. Sabin, The Children's Hospital

Research Foundation, Univ of Cincinnati, Coll. Med. Elland and Bethesda Avenues Cincinnati 29, Ohio, USA.
Dr. T.F. McN. Scott, Children's Hospital, 1740 Bainbridge Street, Philadelphia 47, Pa., USA.

Dr. T.M. Rivers, Hosp. of Rockefeller Inst. 66th St., and York Ave., New York 21, N. Y., USA. 